\title{
MORFOLOGIA, PROCESSOS DE SEDIMENTAÇÃO E LITOFÁCIES DOS AMBIENTES MORFO-SEDIMENTARES DA PLANÍCIE COSTEIRA BRAGANTINA, NORDESTE DO PARÁ, BRASIL
}

\author{
Pedro Walfir Martins Souza Filho(*) \& Maâmar El-Robrini(**)
}

\begin{abstract}
The Bragança Coastal Plain is located in the Northeastern of Pará, in the Bragança-Viseu Coaxial Basin (Cretaceous), with an approximate surface area of $1,570 \mathrm{Km}^{2}$. The geometry of the basin and its paleotopography, associated with recent tectonic movements have controlled the distribution and the thickness of the tertiary and quaternary deposits. This coastal plain constitutes a macrotidal $(6 \mathrm{~m})$ depositional system, developed in a hot and humid equatorial climate, with a dry and wet well defined seasons and an annual precipitation averaging $3,000 \mathrm{~mm}$.

The geomorphology of the area is subdivided into three main morphologic realms: (1) alluvial plain, with fluvial channel, levees and flood plain; (2) estuarine plain, with an estuarine channel subdivided into estuarine funnel segment, straight segment, meandering segment and upstream channel, tidal creek and, floodplain and; (3) coastal plain, with salt marsh (inner and outer), tidal plain (supratidal mangroves, intertidal mangroves and sand flats with tidal shoals), chenier, coastal dunes and beach environments.

The recent morpho-sedimentary units are separated from highland by a line of inactive cliffs that is situated $25 \mathrm{~km}$ from the coastline. This cliffs mark the higher Holocene sea level, very well knowed in brazilian east coast as Holocenic Transgression (5,100 years B.P.). During this event was deposited a basal transgressive sequence (S1), constituted by estuarine sand and mud and marine sand. Afterwards, under regressive or stillstand sea level the mangrove deposits prograde over the transgressive sand sheet building a prograding sequence (S2). Nowadays, this sequence are being overlain by a recent transgressive sequence (S3).

The sedimentary model, based on lithostratigraphy and sedimentary processes, proposed to Bragança Coastal Plain show a complex coastal depositional system, constituted by different sedimentary environments with singular sedimentary, stratigraphic and morphologic characteristics in relation to its geometry and spacial distribution of the environments.

The morpho-sedimentary unit show that the environments studied from the alluvial plain to coastal plain represent a dynamic area dominated by macrotides and influenced by waves along the shoreline. Therefore, the depositional model proposed is composed by a coastal plain depositional system with fluvial-estuarine-tidal flat environments with dune-beach ridge associated.
\end{abstract}

\section{INTRODUÇÃ̃O}

As planícies costeiras dominadas por marés têm sido objeto de estudos em todos os litorais do mundo (Larsonner 1975; Faria Jr. et al. 1987; El-Robrini 1992; Martin et al. 1993; Woodroffe et al. 1986; Dalrymple et al. 1990; Dalrymple et al. 1992; Domingues et al. 1992; Franzinelli 1992; Allen \& Posamentier 1994; Woodroffe \& Mulrennan 1993; Mendes 1994). No entanto poucos trabalhos versam sobre as planícies lamosas densamente colonizadas por mangues, como aquelas que ocorrem nas regiões tropicais quentes e úmidas do Norte do Brasil, Península da Malasia (Kamaludin 1993) e Austrália (Semeniuk 1981; 1993).

O litoral NE do Pará perfaz $600 \mathrm{~km}$ de extensão, indo desde a foz do Rio Pará até a foz do Rio Gurupi. Franzinelli $(1982,1992)$ caracterizou dois tipos de costa nesta região: (1) uma costa transgressiva alta e (2) uma costa transgressiva baixa, onde está inserida a Planície Costeira Bragantina. Este setor vem sofrendo um processo de subsidência, provavelmente relacionado a eventos neotectônicos de reativação de falhamentos normais (Costa et al. 1993; Igreja, 1991).

A costa de submersão é referida neste trabalho como uma costa embaiada, transgressiva e dominada por maré. Franzinelli $(1982 ; 1992)$ compartimentou esta costa em dois setores: (1) a oeste da Baía de Pirabas, onde as baías costeiras recortam as falésias ativas do Planalto Costeiro e; (2) a leste, onde o Planalto Costeiro recua em direção ao sul, constituindo falésias mortas e as baías recortam a planície costeira.

El-Robrini \& Souza Filho (1992a; em preparação) admitem que durante o Pleistoceno Terminal, o nível do mar beirava a atual quebra do talude e a partir deste evento, o nível do mar continuou a subir até o Holoceno (6.000 anos A.P.), afogando parcialmente as planícies costeiras. Esta subida do nível do mar está evidenciada pela presença de falésias mortas esculpidas no Planalto Costeiro.

É dentro desse contexto que está inserida a Planície Costeira Bragantina (Figura 1), onde a distribuição dos ambientes morfo-sedimentares está intimamente relacionada ao regime de macromarés com seis metros de amplitude, dominante nesta área (DHN 1995). O estudo integrado da morfologia, sedimentologia, estratigrafia, oceanografia e botânica contribuem para um melhor entendimento dos processos evolutivos atuantes nessa planície costeira. 


\section{ÁREA DE ESTUDO}

O termo Planície Costeira Bragantina (NE do Pará) é aqui utilizado para a faixa costeira do Município de Bragança, que se estende da Ponta do Maiaú até a foz do Rio Caeté, perfazendo uma área de $1.570 \mathrm{~km}^{2}$ (Figura 1).

O clima da área é do tipo Am2 (segundo adaptação da classificação de Köppen). É caracterizado por ser quente e úmido, com estação seca prolongando-se de junho a novembro, e um período chuvoso bem acentuado, com fortes chuvas nos demais períodos do ano (dezembro a maio), apresentando pluviosidade média anual variando de 2.500 a $3.000 \mathrm{~mm}$ e umidade relativa do ar entre 80 e $91 \%$ (Martorano et al. 1993).
A posição geográfica do NE do Estado Pará $\left(0^{\circ}-1^{\circ}\right.$ S), aliada a seus embaiamentos costeiros e grande extensão da Plataforma Continental do Pará/Maranhão proporcionam o desenvolvimento de um ambiente de alta energia, dominado por macro-marés semi-diurnas com amplitudes variando de 4 a 6 m (DHN 1995).

A vegetação desta região está enquadrada no contexto das florestas secundárias sobre o planalto costeiro e das formações pioneiras, representadas pela vegetação de mangue, campos herbáceos e campos arbustivos sobre a planície costeira (Figura 2).

A vegetação de mangue ocupa toda a Planície Costeira Bragantina, penetrando em direção ao continente ao longo dos canais estuarinos (Figura 2). Essa vegetação ocupa as áreas sob influência de águas

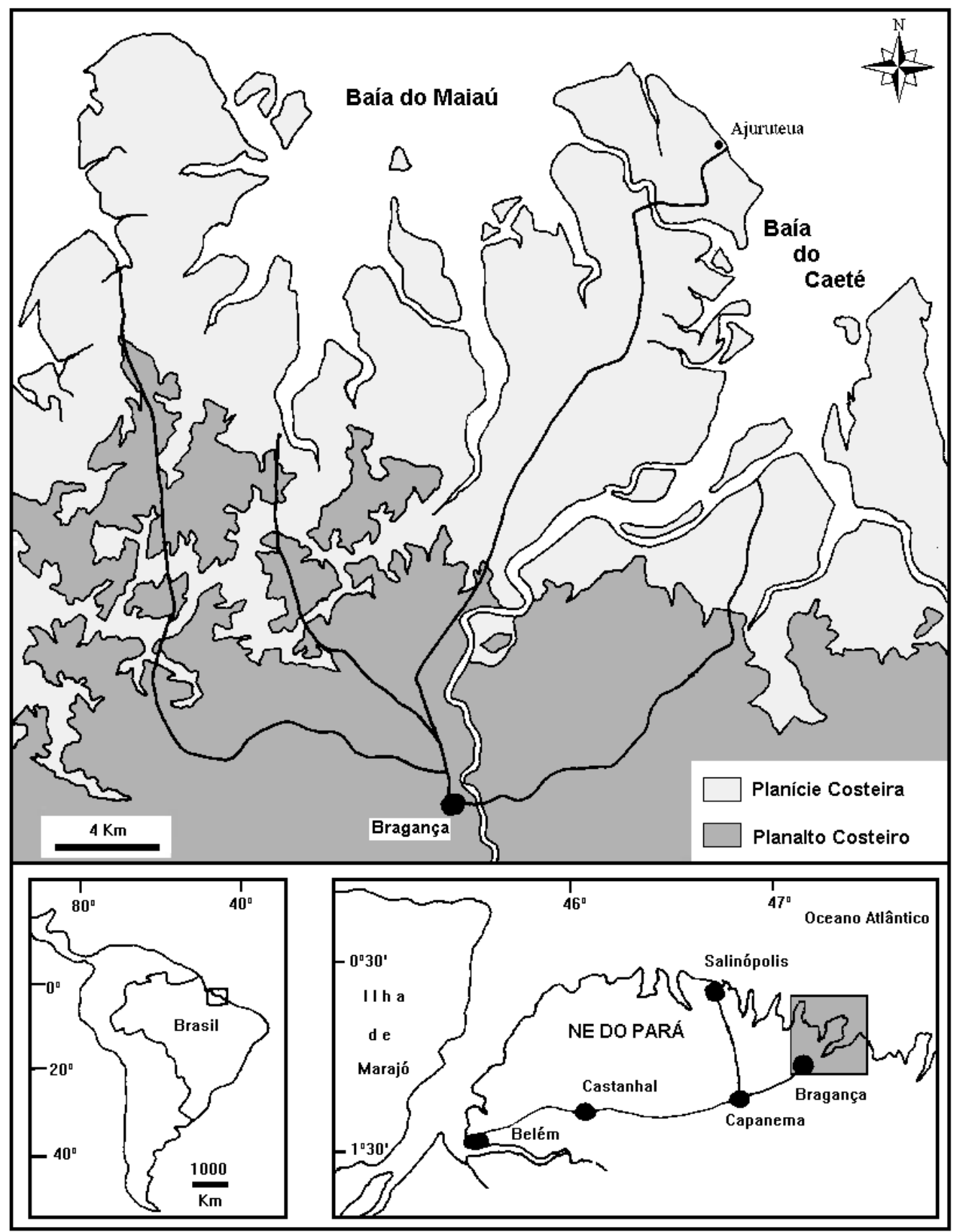

Figura 1: Mapa de localização da Planície Costeira Bragantina.

Figure 1: Localization map of Bragança Coastal Plain. 
salinas e salobras, sendo constituída somente por comunidades típicas. Os gêneros dominantes são Rhyzophora L., Avicenia L. e Lagunculária L. Associada a esta vegetação, ocorre Spartina sp. e Conocarpus L.(Figura 2).

A vegetação de campo ocorre em áreas periodicamente alagadas, sob influência pluvial e de águas salobras. É representada pelos pântanos salinos, colonizados predominantemente por Aleucharias sp. (juncos) (Figura 2).

Os campos arbustivos ocorrem sobre cheniers e campos de dunas. São representados por Chrysobalanus icaco L. (ajuru); Anacardium occidentale L. (caju) e Byrsonma crassifolia H.B.K. (muruci), com gramineae e cyperaceae associada (Figura 2).

A área em estudo integra a bacia costeira cretácica de Bragança-Viseu, que representa uma fossa tectônica delimitada por falhas normais de direção NW-SE, (Aranha et al. 1990), cujo embasamento pré-cambriano é composto por um mosaico de blocos cratônicos (Abreu \& Lesquer 1985), sedimentos cambroordovicianos (Formação Bequimão) e unidades eopaleozóicas (Seqüência Piriá-Camiranga) (Igreja 1991). O Mesozóico é representado pelas formações CodóGrajaú, Itapecuru Inferior e Itapecuru Superior (Aranha et al. 1990). O Terciário é marcado inicialmente pela sedimentação calcárea da Formação Pirabas (Maury in Goes et al. 1990) e dos sedimentos clásticos do Grupo Barreiras, no Mioceno Inferior (Figura 3), os quais constituem os sedimentos aflorantes do Planalto Costeiro (Arai et al. 1988; 1994; Rossetti et al. 1989). O Quaternário é representado por sedimentos arenoargilosos pleistocênicos do Pós-Barreiras (Sá 1969), e por depósitos da planície aluvionar, estuarina e costeira.

\section{METODOLOGIA}

Os métodos e equipamentos utilizados durante a realização deste trabalho incluíram atividades de sensoriamento remoto, geoprocessamento, testemunhagem à vibração, análises sedimentológicas e faciológicas.

Inicialmente, foram selecionadas cenas de satélite LANDSAT, fotografias aéreas e imagens de radar. As cenas de satélite TM do LANDSAT-5 (24/07/1991; órbita-ponto 222-61) foram processadas digitalmente através do Sistema de Tratamento de Imagens (SITIM, 340) e através do Sistema REMBRANDT. Foram obtidas fotografias ampliadas em papel fotográfico e slides cobrindo toda a área nas bandas 3, 4 e 5, além da composição colorida 5R 4G 3B, definidas como a melhor composição para o estudo das áreas de manguezais.

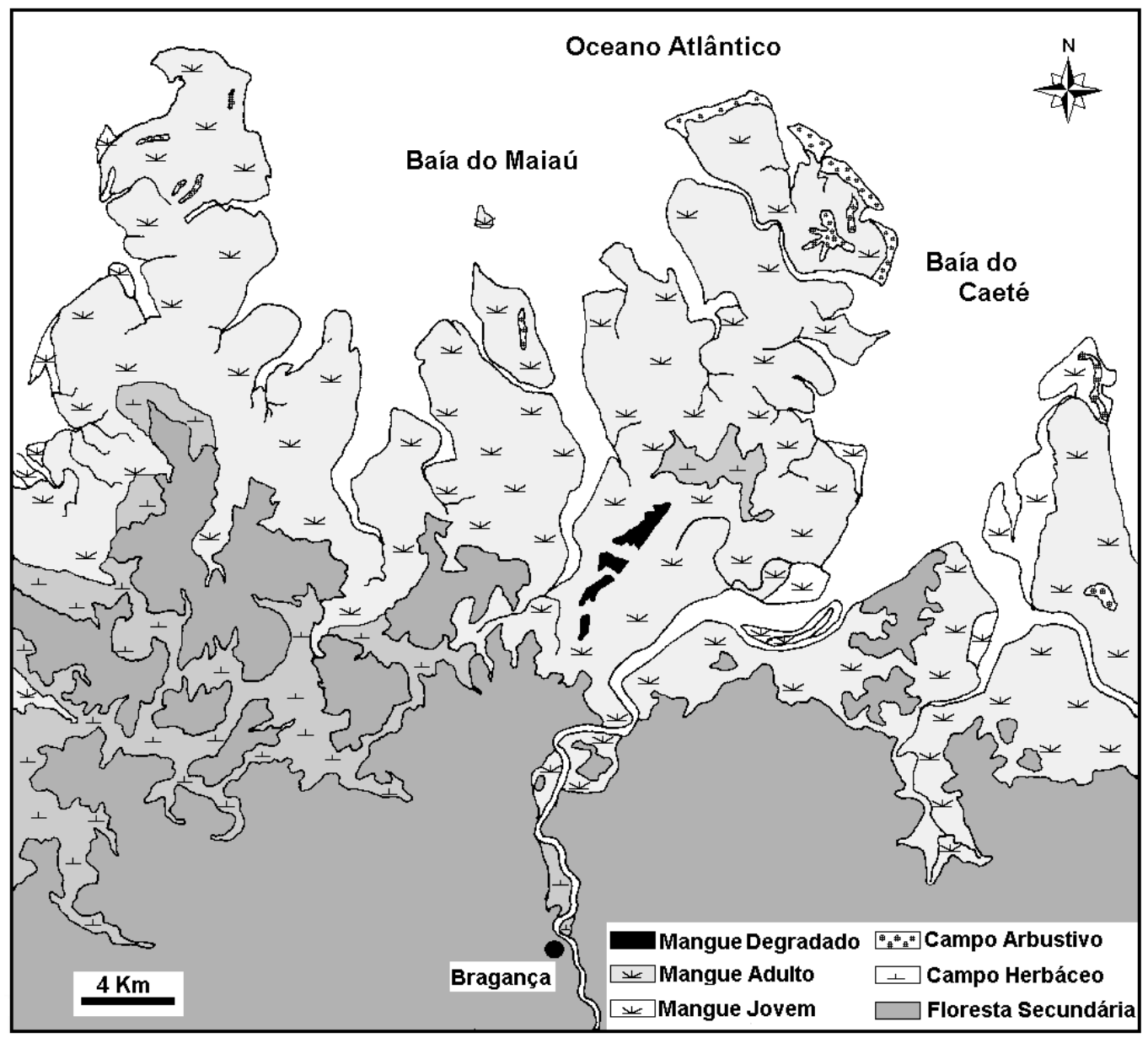

Figura 2: Mapa de vegetação da Planície Costeira Bragantina.

Figure 2: Vegetation map of Bragança Coastal Plain. 
As fotografias aéreas em escala 1:25.000 são datadas de 1977 e as imagens de radar (banda X) foram obtidas em 1972 com Radar Gems 1000, editado em 1977 durante a realização do Projeto RADAMBRASIL.

Os levantamentos de campo foram necessários para complementar e/ou corrigir as classificações temáticas iniciais, bem como para a identificação dos tipos de vegetação e de sedimentos.

Foram realizados 35 testemunhagens à vibração. Após a coleta, os testemunhos foram marcados e processados, segundo técnicas descritas por Figueiredo Jr. (1990). Na descrição dos testemunhos foram identificadas as estruturas e texturas sedimentares.

Na descrição preliminar dos testemunhos, utilizouse a carta de cores do "The Rock-Color Chart Committee" (1984) e uma tabela comparativa de grãos.

O estudo da distribuição granulométrica foi realizado somente em amostras predominantemente arenosas, utilizando-se métodos clássicos descritos por Suguio (1973). O objetivo desta análise foi quantificar as frações arenosas dos intervalos do testemunho analisados, para obtenção dos parâmetros estatísticos (mediana, média, selecionamento e assimetria) para caracterização textural dos sedimentos.

\section{DOMÍNIOS MORFO-SEDIMENTARES}

A Planície Costeira Bragantina foi compartimentada em três domínios morfológicos distintos (Figura 4), segundo sua forma, natureza dos sedimentos, estratigrafia e vegetação dominante: (1) Planície Aluvial; (2) Planície Estuarina e; (3) Planície Costeira (Souza Filho 1995; Souza Filho \& El-Robrini 1995). A Tabela 1 sintetiza as principais unidades morfológicas da área em estudo.

No detalhe, várias unidades morfológicas foram reconhecidas, a partir de suas características fisiográficas, sedimentológicas, tipo de sedimentação e vegetação.

\section{Planalto Costeiro}

Corresponde ao embasamento da Planície Costeira Bragantina, sendo constituído por sedimentos do Grupo Barreiras. Representa uma superfície plana arrasada, suavemente ondulada e fortemente dissecada, com cotas entre 50 e $60 \mathrm{~m}$, que diminuem progressivamente em direção à planície costeira, a norte (Costa et al. 1977). Este contato é marcado por uma mudança litológica (sedimentos areno-argilosos avermelhados do Grupo Barreiras e lamosos da planície costeira), vegetacional (floresta secundária e mangue, Figura 5) e morfológica brusca (falésias mortas de até $1 \mathrm{~m}$ de altura).

\section{Planície Aluvial}

Estende-se a sul do limite da maré na planície estuarina, à altura de Bragança, abrangendo uma área de $3.1 \mathrm{~km}^{2}$ (Figura 4), sendo subdividida em três unidades:

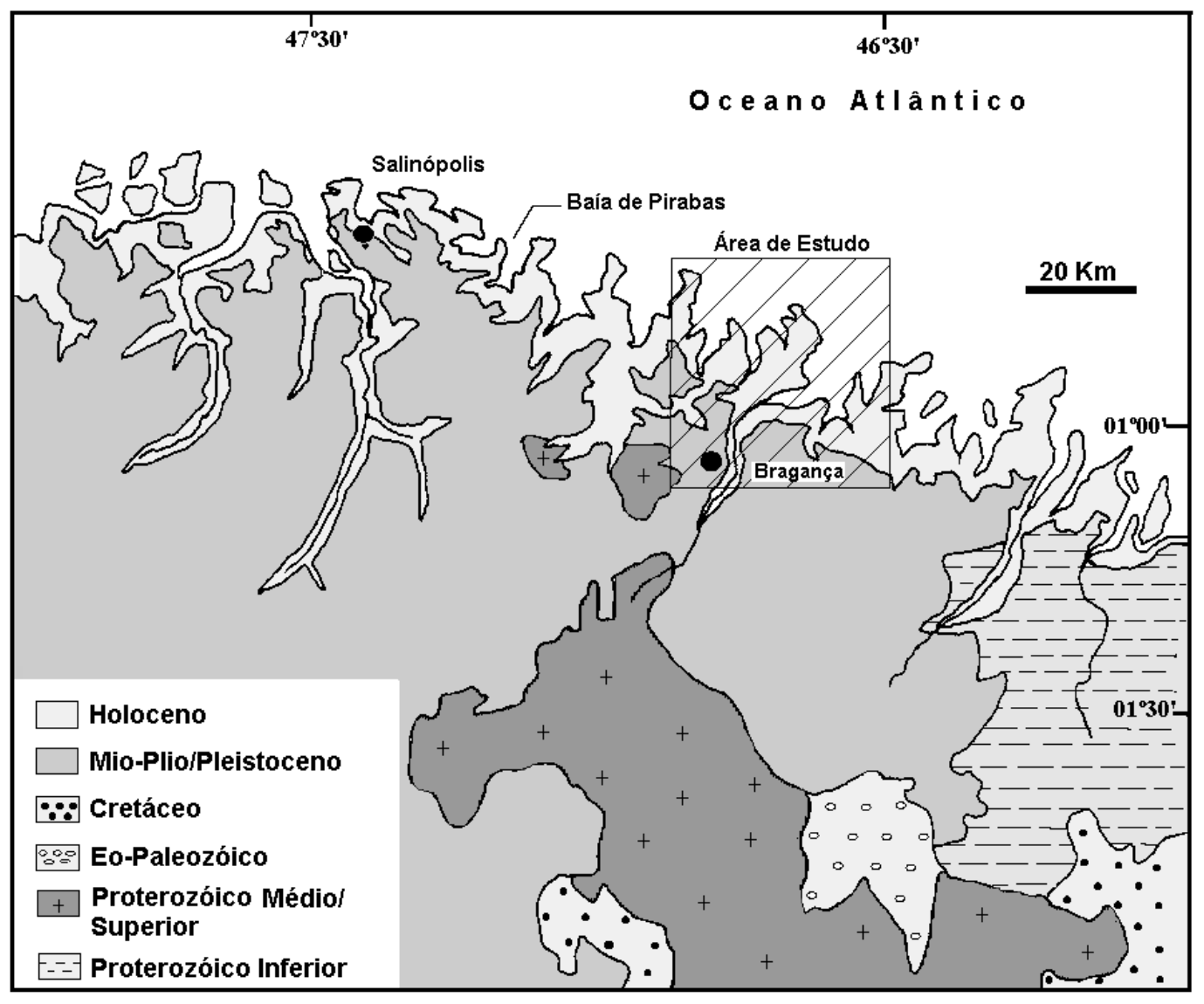

Figura 3: Mapa geológico do NE do Pará (Modificado de COSTA et al. 1977 e ABREU \& LESQUER 1985). Figure 3: Geologic map of Northeast of Pará (Modified from COSTA et al. 1977 e ABREU \& LESQUER 1985). 


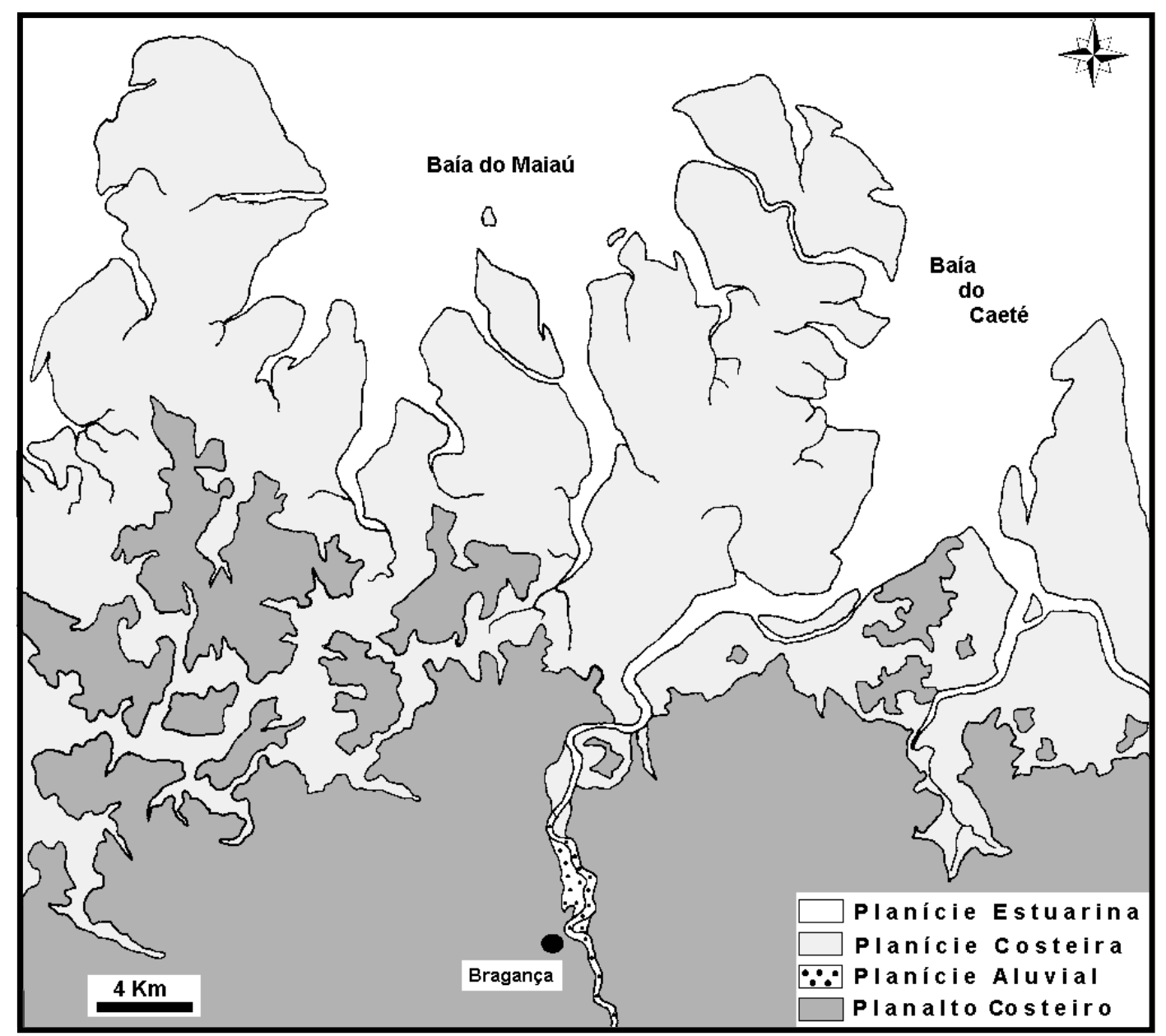

Figura 4: Domínios morfológicos da Planície Costeira Bragantina. Figure 4: Morphological compartments of Bragança Coastal Plain.

(1) Canal Fluvial do Rio Caeté: apresenta um canal meandrante, com anomalias em caixa e cotovelo, com depósitos de barras em pontal e longitudinais, encaixados no Planalto Costeiro (Figura $6 \mathrm{~A}$ );

(2) Planície de Inundação: limitada por diques marginais (levees) e pelo Planalto Costeiro, sendo colonizadas por campos herbáceos, principalmente por Eleucharias sp. (Figura 6 A e B) e inundados somente durante os períodos de grandes cheias, quando ocorre o transbordamento dos canais e os sedimentos mais finos são acumulados sobre esta área e;

(3) Diques Marginais (levees): são elevações longitudinais construídas $50 \mathrm{~cm}$ acima da planície de inundação, adjacente ao canal fluvial, vegetados por mangues e Eleucharia sp (Figura 6 A e B), sendo rompidos durante os períodos de grandes cheias, no momento do transbordamento.

\section{Planície Estuarina}

É limitada a sul pela planície aluvial no limite superior da influência das marés, e a norte pela zona onde dominam os processos marinhos. É margeada pela planície costeira em sua porção distal e pelo Planalto Costeiro na proximal, ocupando uma área de $462 \mathrm{~km}^{2}$ (Figura 4). Três unidades morfológicas são observadas:

(1) Canal Estuarino do Rio Caeté: varia da porção distal para a proximal, refletindo progressivamente a influência das marés ao longo do canal estuarino. É compartimentado em quatro padrões morfológicos distintos (Figura 7), semelhante à subdivisão proposta por Woodroffe et al. $(1986,1989)$ para o Rio Aligator na Austrália.

-Funil Estuarino: representa a foz do estuário (7.5 $\mathrm{km}$ de largura) e mostra um alargamento brusco em direção ao mar. É bordejado por depósitos de manguezais e pela planície arenosa (constituem sua planície de inundação) e, localmente, pelo Planalto Costeiro. Barras arenosas de marés e ilhas de manguezais são freqüentes e estão amplamente distribuídas nesse trecho do estuário;

-Segmento Retilíneo: é dominado por fortes correntes de marés e os sedimentos são transportados em direção a montante. É bordejado por terraços de abrasão esculpidos nos depósitos de manguezais, submersos durante as marés altas. Barras arenosas de maré também ocorrem ao longo desse trecho;

-Segmento Meandrante: limitado por falésias esculpidas em sedimentos do Planalto Costeiro, sobre o qual desenvolve-se a planície de inundação, colonizada por mangue e gramíneas. Na parte côncava dos meandros, as margens são erosivas, enquanto que na parte convexa ocorrem os depósitos de barra em pontal. 


\begin{tabular}{|c|c|c|c|}
\hline $\begin{array}{l}\text { Domínios } \\
\text { Morfológicos }\end{array}$ & $\begin{array}{l}\text { Unidades } \\
\text { Morfológicos }\end{array}$ & Área (Km2) & Área \% \\
\hline Planalto Costeiro & 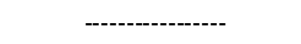 & 493 & \\
\hline \multirow{3}{*}{ Planície Aluvial } & Canal Meandrante & \multirow{3}{*}{3,1} & \multirow{3}{*}{0,25} \\
\hline & Planície de Inundação & & \\
\hline & Diques Marginais & & \\
\hline \multirow[t]{3}{*}{ Planície Estuarina } & $\begin{array}{l}\text { Canal Estuarino (funil } \\
\text { estuarino, segmento } \\
\text { retilíneo, segmento } \\
\text { meandrante, canal de } \\
\text { curso superior) }\end{array}$ & \multirow{3}{*}{462} & \multirow{3}{*}{42,70} \\
\hline & Córregos de maré & & \\
\hline & Planície de inundação & & \\
\hline \multirow{6}{*}{ Planície Costeira } & $\begin{array}{c}\text { Pântano Salino (Interno e } \\
\text { externo) }\end{array}$ & 82,7 & 7,70 \\
\hline & $\begin{array}{c}\text { Manguezal (Supramaré e } \\
\text { Intermaré) }\end{array}$ & 471 & 43,61 \\
\hline & Chenier & 5,5 & 0,50 \\
\hline & Planície Arenosa & 49 & 4,53 \\
\hline & Dunas Costeiras & 6,4 & 0.60 \\
\hline & Praia & ----- & ----- \\
\hline
\end{tabular}

Tabela 1: Principais domínios morfológicos da área em estudo, suas unidades e área de abrangência. Table 1: Main morphological compartments of the study area, its units and extension.

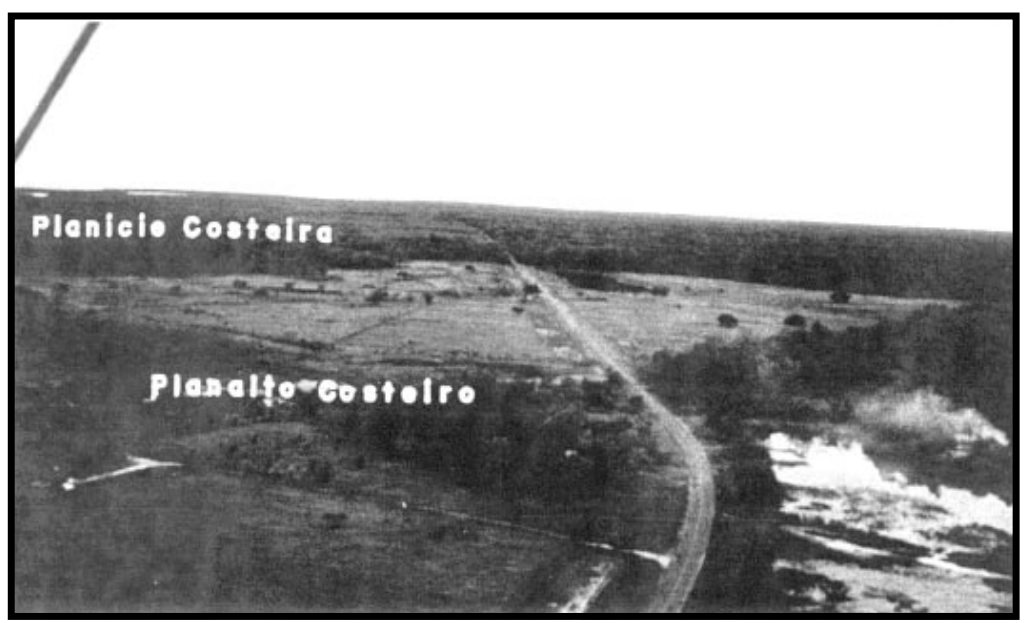

Figura 5: Limite entre o Planalto e a Planície Costeira Bragantina. Notar o contato brusco entre a vegetação de floresta secundária sobre o Planalto Costeiro e a vegetação de manguezal da Planície Costeira.

Figure 5: Boundary between highland and Bragança Coastal Plain. Note the strong boundary between the vegetation of secundary florest over the highland and the mangrove vegetation of the costal plain.

- Canal de Curso Superior: encontra-se encaixado no Planalto Costeiro, mostrando alternância de segmentos retos e sinuosos, espaçados irregularmente. Franjas de manguezal bordejam o canal, onde barras em pontal e longitudinais são freqüientes.

(2) Canais de Maré: recortam a planície costeira e apresentam forma meandrante a retilínea, com largura máxima de 100m. Em direção ao continente, são bifurcados, rasos, estreitos e com substrato lamoso; em direção ao mar, os mesmos são singulares e largos, com fundo arenoso. São freqüentes barras em pontal.

(3) Planície de Inundação: ocorre ao longo do funil estuarino e dos segmentos retilíneos e meandrantes, onde são observados depósitos lamosos. No canal de curso superior, as planícies de inundação são constituídas por sedimentos pelíticos fitoturbados, ricos em matéria orgânica. Às margens desse trecho, ocorrem estreitas franjas de manguezal, seguidas por gramíneas e palmeiras que colonizam a planície de inundação e desaparecem quando entram em contato com o Planalto Costeiro. 


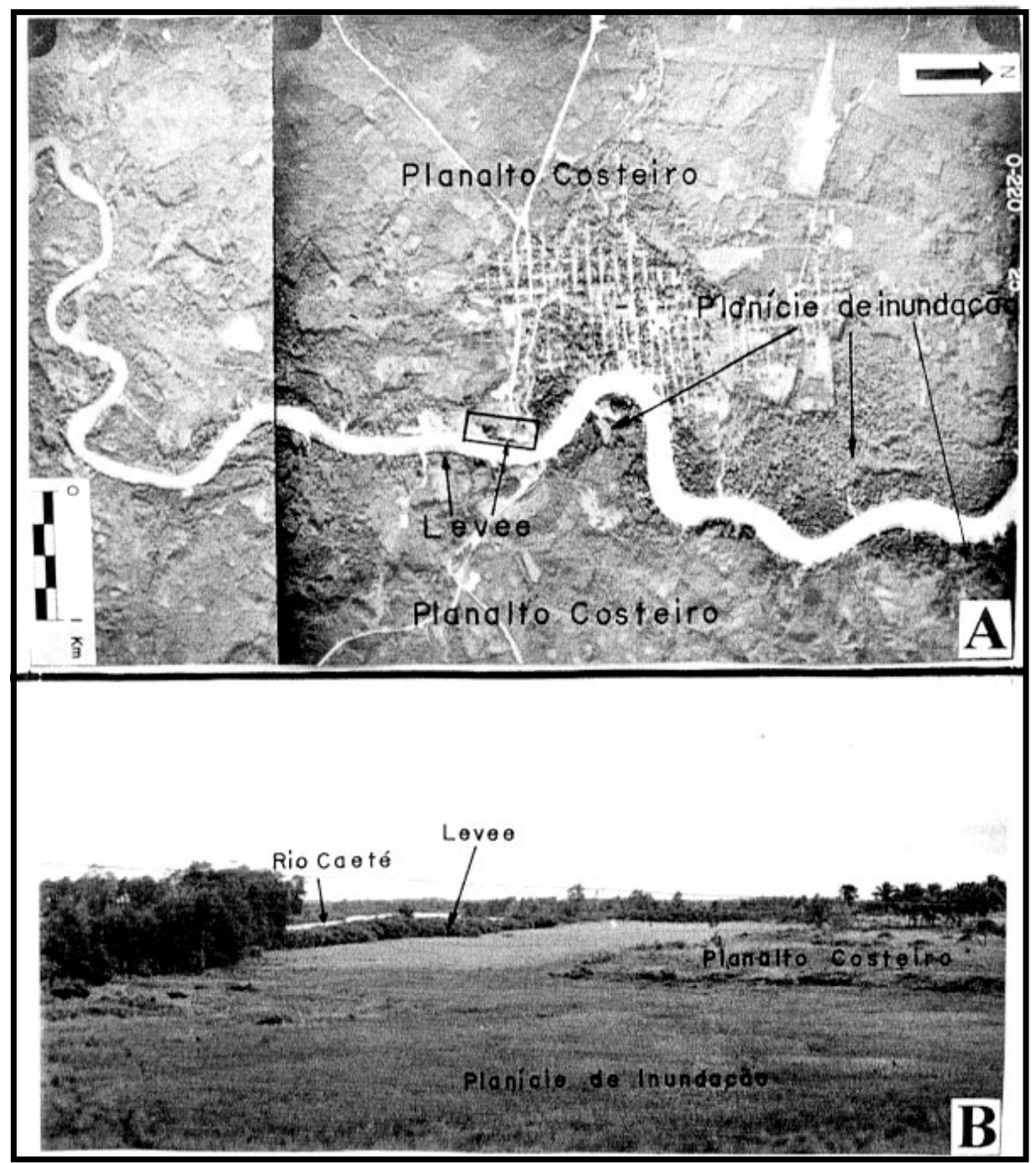

Figura 6: A)Planície aluvial do Rio Caeté, mostrando o canal meandrante, planície de inundação, diques marginais e o Planalto Costeiro. B) Detalhe da fotografia aérea, mostrando as unidades acima citadas.

Figure 6: A) Alluvial plain of Caeté River showing the meandering channel, flood plain, levees and highland. B) Detail of aerial photography, showing the units over cited.

\section{Planície Costeira}

É o mais extenso dos domínios morfológicos, abrangendo uma área de $615.7 \mathrm{~km}^{2}$. É limitada à sul por falésias mortas de 1 a $2 \mathrm{~m}$ de altura, esculpidas no Planalto Costeiro e, a norte pela zona onde predominam os processos marinhos. É recortada pela planície estuarina (Figura 4). Seis unidades foram identificadas nesse domínio:

\section{(1) Pântanos Salinos}

Os pântanos salinos ou "Campos de Bragança" ocupam uma área de $82.7 \mathrm{~km}^{2}$. Estão sob influência do domínio de supramaré e encaixados em uma rede de drenagem colmatada, alimentada principalmente por sedimentos finos fluviais e oriundos da planície de maré lamosa. São subdivididos em: a) Pântanos Salinos Internos, alagados durante o período chuvoso, e seco durante o período de estiagem e; b) Pântanos Salinos Externos, situados no limite do Planalto Costeiro com a floresta secundária, e da planície costeira lamosa com a vegetação de mangue. Apresentam a mesma morfologia, diferindo dos pântanos salinos internos, apenas pela influência das marés e por apresentarem características estratigráficas peculiares. Os pântanos são colonizados por Eleucharias sp. (juncus) e limitados pela floresta degradada sobre o Planalto Costeiro (Figura 8 A e B).

\section{(2) Manguezais}

Constituem extensas planícies lamosas de até $20 \mathrm{~km}$ de largura, situadas entre os níveis da maré alta de sizígia e a média das marés, ocupando uma área de 466.8 km². São constituídos por sedimentos lamosos colonizados, principalmente, por Ryzophora L. e Avicenia L, além de Laguncularia L. e Spartina L. associados.

Baseado nas marés, altimetria relativa e porte da vegetação de mangue, estes depósitos foram subdivididos em: a) Manguezal de Supramaré, topograficamente mais elevado, com menor porte arbóreo e influenciado pelas marés somente durante os períodos de sizígia e; 


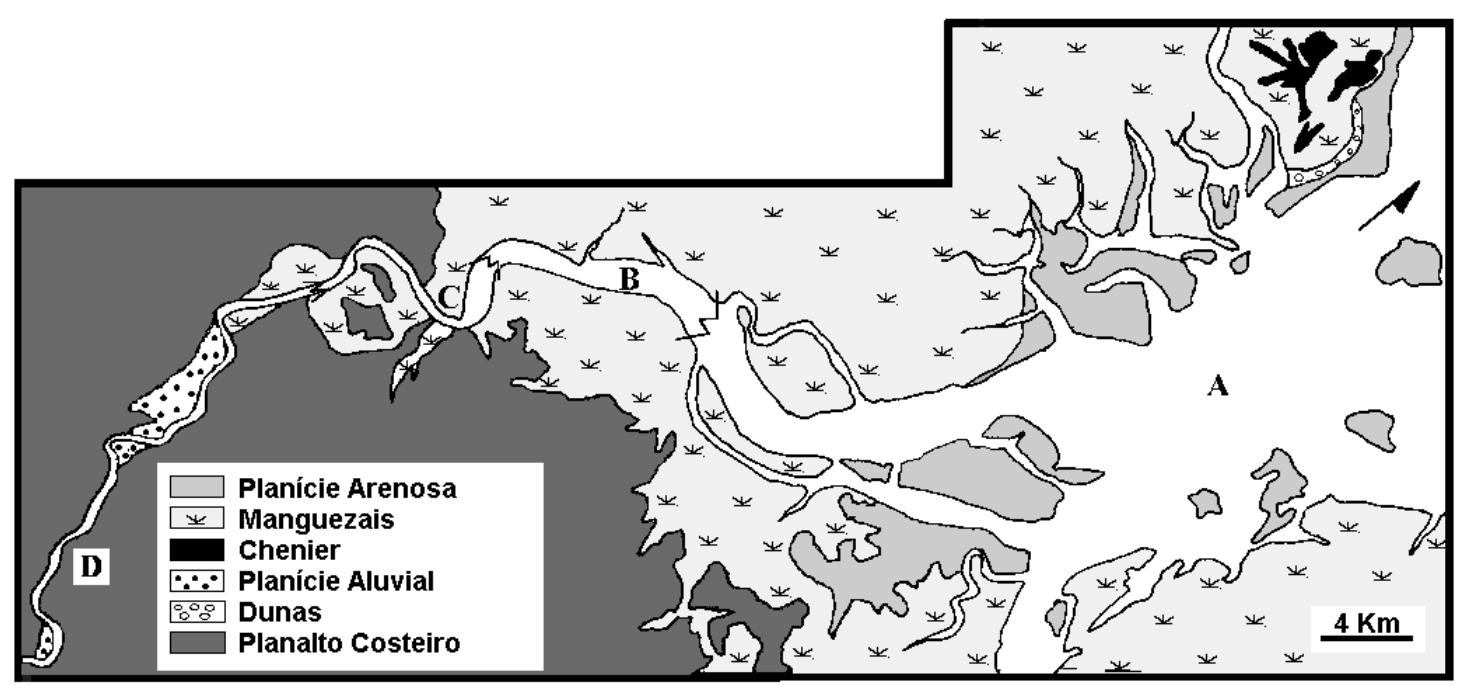

Figura 7: Planície estuarina do Rio Caeté e os diferentes padrões morfológicos do canal estuarino e subunidades limitrofes. A- funil estuarino; $B$ - segmento retilineo; $C$ - segmento meandrante; $D$ - canal de curso superior.

Figure 7: Estuarine plain of Caeté River and the differents morphologic patterns of the estuarine channel and the subunits boundaries. A- estuarine funnel; B- straight segment; $C$-meandering segment; $D$ - upstream segment.

b) Manguezal de Intermaré, topograficamente mais baixo, maior porte arbóreo, com frentes de progradação colonizadas por mangues jovens que bordejam a planície costeira (Figura $8 \mathrm{C}$ ).

\section{(3) Cheniers}

Ocupam uma área de $5.5 \mathrm{~km}^{2}$ e são constituídos por cordões de duna-praia (dune-beach ridges) de até $3 \mathrm{~m}$ de altura e leques de lavagem que dão forma irregular aos corpos (Figura $8 \mathrm{C}$ ). Comumente apresentam forma alongadas de cordões de praia (beach ridges), com ou sem leques de lavagem, com não mais do que $1 \mathrm{~m}$ de altura, $200 \mathrm{~m}$ de largura e $2 \mathrm{~km}$ de comprimento (Figura $8 \mathrm{D}$ e E).

\section{(4) Planície Arenosa}

Localiza-se na porção distal da planície costeira (49 $\mathrm{km}^{2}$ ), margeando os depósitos de manguezal e dunas costeiras. Esta área é dominada por baixios arenosos a partir do limite das marés baixas de quadratura até a zona de inframaré. Geralmente, esta área apresenta um gradiente baixo (1:100), que, por vezes, é quebrado pela presença de barras arenosas de até $3 \mathrm{~m}$ de altura. As areias formam megaondulações, ondulações de cristas retas, lunadas, rombóides e lingóides, além de sand waves e fundos planos (Figura $8 \mathrm{~F}$ ).

\section{(5) Dunas Costeiras}

São limitadas a sul por manguezais de intermaré e a norte pela planície arenosa, perfazendo uma área de 6.4 $\mathrm{km}^{2}$. Os cordões de dunas mais freqüentes são formados por dunas fixadas por campos arbustivos, que constituem cristas paralelas à linha de costa, produzidas pela estabilização de dunas longitudinais (Figura 9 A) e piramidais (Figura 9 B) de aproximadamente $7 \mathrm{~m} \mathrm{e} 5 \mathrm{~m}$ de altura, respectivamente. Essas dunas formam cristas não muito paralelas uma a outra, o que reflete a história acrecional da linha de costa. Tais dunas encontravam-se acima do nível de maré alta média, mas atualmente estão sendo erodidas por ondas e correntes de marés e/ou dissipadas, constituindo falésias ao longo da linha de costa (Figura 9C). Dunas barcanóides e piramidais não fixadas, ocorrem sobre o pós-praia, constituindo um campo de dunas móveis com cerca de 0,5 a $1 \mathrm{~m}$ de altura, que migra em direção ao continente.

\section{(6) Praia}

As praias bordejam a planície de maré lamosa (manguezal de intermaré), sendo recortada pelos canais de marés. São representadas por cordões arenosos (beach ridges) lineares, que migram em direção ao continente sobre os depósitos de manguezais, constituindo uma costa retrogradacional. A praia é subdividida em:

-Pós-Praia: limitada em direção ao mar pelo nível de maré alta (escarpa de praia) e, em direção ao continente, por dunas costeiras. Apresenta cerca de $200 \mathrm{~m}$ de extensão. É representada por uma superfície aproximadamente horizontal, sobre a qual desenvolvemse pequenas dunas e;

-Estirâncio: representa a face de praia propriamente dita e está limitado pelos níveis de maré alta e baixa, correspondendo a zona de intermaré. Constitui uma zona levemente inclinada em direção ao mar (2-3 ${ }^{\circ}$, muito extensa $(\sim 700 \mathrm{~m})$, onde observa-se um sistema de cristas e calhas (ridges e runnels), dispostos paralelamente a linha de costa e interligados por canaletas (gaps) (Figura 9 D).

\section{LITOFÁCIES E PROCESSOS DE FORMAÇÃO DAS UNIDADES MORFO-SEDIMENTARES}

\section{Pântanos Salinos}

\section{Litofácies (lama)}

Esta unidade apresenta uma espessura máxima de $5 \mathrm{~m}$ e é constituída, na porção inicial (10 cm superficiais), por lama rica em matéria orgânica fragmentada, apresentando, por essa razão, coloração preto 
A
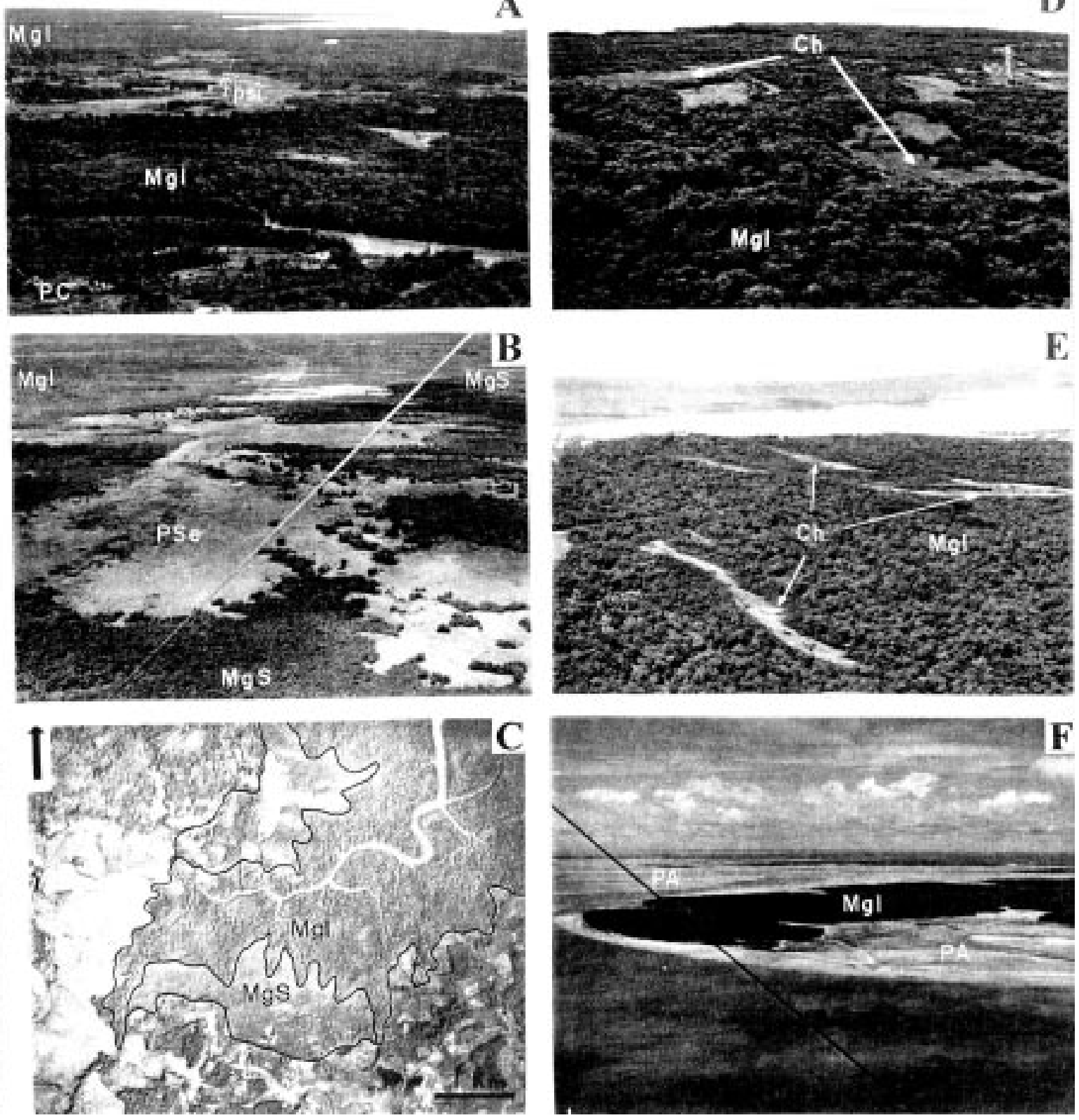

Figura 8: Padrões morfológicos da Planície Costeira Bragantina. A) Pântano Salino Interno; B)Pântano Salino Externo; C) Transição Pântano Salino Externo, Manguezal de Intermaré e de Supramaré; D) Chenier com cristas irregulares; E) Cheniers com cristas lineares; F) Planície Arenosa bordejando os manguezais de intermaré.

Figure 8: Morphologic patterns of Bragança Coastal Plain. A) Inner salt marsh. B) Outer salt marsh. C) Transition between upper salt marsh, intertidal and supratidal mangrove. D) Cheniers with irregular ridges. E) Cheniers with linear ridges. F) Sand flat boundaring the intertidal mangrove.

amarronzado (5 YR 5/6). Os sedimentos subsequentes (10 a $30 \mathrm{~cm})$ são constituídos por lama oxidada, de coloração cinza oliva claro (5 Y 6/1) com manchas marrom amarelo pálido (10 YR 6/2) e marrom claro (5 YR 5/6). Os $480 \mathrm{~cm}$ subsequentes são representados por lama de coloração cinza médio (N5), sem estruturação aparente, o que segundo Bouma (apud Frey \& Basan 1978) seria decorrente da deposição de argilas na forma de flocos ou grânulos de granulometria maior. São comuns lentes de areia fina intercaladas com lama, caracterizando acamamento lenticular simples. Feições de bioturbação também ocorrem no pacote lamoso (Figura $10 \mathrm{~A})$.

\section{Sedimentação}

Os processos físicos controlados principalmente pelas marés, são de grande importância no desenvolvimento deste ambiente. Nos pântanos salinos, a sedimentação ocorre a partir da concentração de sedimentos trazidos da planície de maré, no momento em que a energia das correntes descresce em direção a este ambiente. Em regra geral, os sedimentos finos são transportados em suspensão, antes da decantação final. A decantação de sedimentos em suspensão não é suficiente para explicar a grande espessura dos depósitos lamosos encontrados (Figura 10 A). Segundo Pryor 
(1975), outros mecanismos contribuem significantivamente para que isso ocorra, como os processos de floculação físico-química das argilas, formação de organo-argilas e trapeamento de sedimentos biogênicos. Durante a época de chuvas, bastante marcante na região, a contribuição de sedimentos oriundos dos rios é maior, a exemplo do que ocorre em pântanos deltáicos (Coleman, in Frey \& Basan 1978).

\section{Manguezais}

\section{Litofácies (lama bioturbada)}

Esta unidade apresenta espessura que varia de 3 a 8 m. Os $40 \mathrm{~cm}$ superficiais são constituídos por lama orgânica oxidada, de coloração amarelo escuro (5 Y 6/4), com manchas marrom claro (5 YR 5/6), bastante fitoturbada, com marcas e fragmentos de raízes (Figura $10 \mathrm{~B})$. No intervalo de 40 a $430 \mathrm{~cm}$, é possível observar um pacote de lama orgânica de coloração cinza médio (N5), sem estrutura física aparente, mas fitoturbado como mostram as marcas e fragmentos de raízes, representativo da planície de intermaré lamosa. De 430 a $540 \mathrm{~cm}$, ocorre um intervalo marcado pela intercalação de estratos lamosos e arenosos com (coffee grounds), inclinados cerca de $35^{\circ}$, caracterizando umaestratificação heterolítica inclinada, representativa de barras em pontal que ocorrem em canais de maré que recortam os manguezais (Figura $10 \mathrm{~B}$ ).

\section{Sedimentação}

Essas planícies lamosas são completamente inundadas, durante as marés de sizígia de equinócios (março e setembro). Nos demais períodos, apenas as planícies de intermaré são alagadas. Os sedimentos lamosos são depositados com a diminuição da velocidade das correntes durante o estofo da maré, uma vez que as correntes de marés não têm energia suficiente para transportar os sedimentos arenosos para este ambiente, exceto durante as marés de sizígia, quando as areias muito finas e os fragmentos orgânicos são transportados em direção aos manguezais.

$\mathrm{O}$ alto teor de sedimentos lamosos neste ambiente está relacionado ao processo de floculação de sedimentos argilosos. Segundo Pryor (1975), o processo de floculação química e física é um mecanismo de geração de aglomerados de partículas de tamanho argila, com

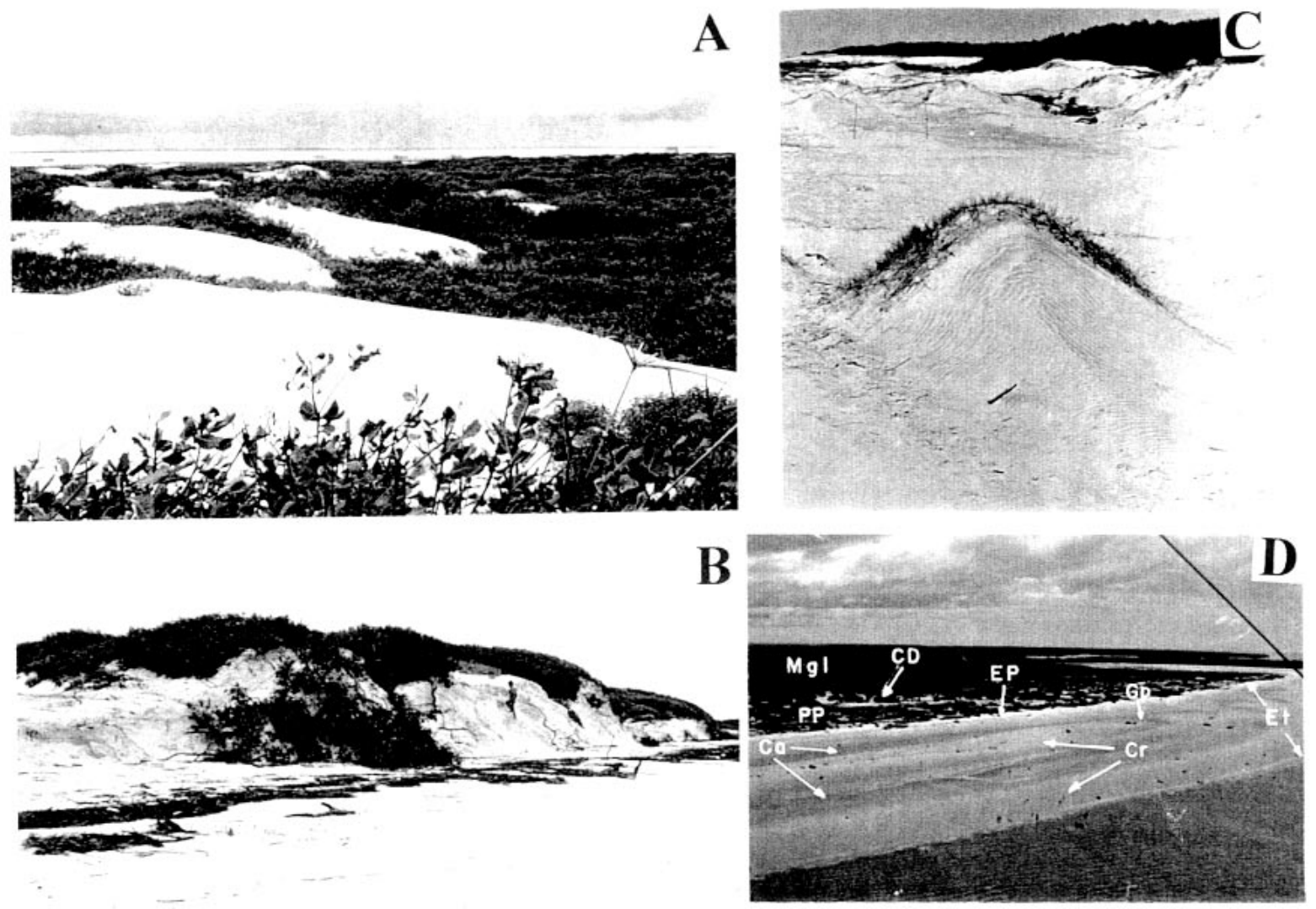

Figura 9: A)Dunas longitudinais vegetadas em Ajuruteua. B)Falésias formadas em dunas longitudinais vegetadas e erodidas por ondas e correntes de marés. C)Dunas piramidais na Ponta do Pilão. D)Praia de Ajuruteua. Notar depósitos de manguezais de intermaré (MgI), separados do pós-praia (PP), por um cordão de dunas $(C D)$ linear. $O$ pós-praia é separado do estirâncio (Et) por uma escarpa de praia (EP). No estirâncio, observar cristas $(C r)$ e calhas (Ca), interligadas por canaletas ("gaps") (Gp).

Figure 9: A) Vegeted longitudinal dunes in Ajuruteua. B) Cliffs formed in vegeted longitudinal dunes and eroded by waves and tidal currents. C) Piramidal dunes in "Ponta do Pilão". D) Ajuruteua Beach. Note deposits of intertidal mangrove $(\mathrm{MgI})$ separated from backshore $(P P)$ by a linear dune ridge $(C D)$. The backshore is separated from the foreshore (Et) by a beach scarp (EP). In the foreshore, observe ridges $(C r)$ and runnels $(C a)$ connected by gaps $(G p)$. 
densidade suficiente para depositar, mesmo em condições de águas pouco agitadas. A floculação é resultante da combinação mineralógica, concentração de sal, compostos orgânicos, diferença de cargas eletrostáticas e da taxa de colisão entre as partículas. A presença da vegetação, principalmente Spartina L., também acelera esse processo, gerando subambientes mais salinos que as áreas adjacentes e mais protegidas da influência das correntes de marés e das ondas.

A atividade biológica nessas áreas é intensa e a principal característica é a estrutura desenvolvida por raízes (1-5 cm de diâmetro), pneumatóforos ( $1-3 \mathrm{~cm}$ de diâmetro) e raízes fibrosas de alimentação (1-3 mm de diâmetro). Restos de fragmentos orgânicos são incorporados aos sedimentos, e organismos os bioturbam, gerando estruturas mosqueadas e tubos que destroem as estruturas originais, cujas laminações raramente são preservadas.

\section{Chenier}

\section{Litofácies (areia fina a muito fina)}

Apresenta uma espessura máxima de $5.5 \mathrm{~m}$ (Figura $10 \mathrm{C})$. A parte superior da sequiência (3m) é constituída por depósitos de dunas, constituídas por areias muito finas, de coloração marrom pálido (10 YR 6/2), bem selecionadas, cujas estruturas primárias estão completamente obliteradas por processos pedogenéticos. No intervalo de 0 a $100 \mathrm{~cm}$, são observados sedimentos arenosos finos, bem selecionados, de coloração marrom amarelado pálido (10 YR 6/2) a laranja muito pálido (10 YR 8/2), bastante bioturbado, com estrutura mosqueada, característico da porção proximal do leque de lavagem, que apresenta uma estratificação horizontal. O intervalo subsequente $(100-130 \mathrm{~cm})$ é marcado por uma estratificação inclinada, mergulhando $23^{\circ}$ em direção ao continente, com alternância de estratos milimétricos de areia fina e coffee ground, caracterizando a estratificação foreset da porção distal do leque de lavagem.

Esta sequência arenosa repousa em discordância erosiva sobre um pacote lamoso de $130 \mathrm{~cm}$ de espessura, coloração cinza médio (N5) e topo marcado por feições de bioturbação preenchidas por areias finas, evidenciando uma superfície de exposição subaérea. Um nível de conchas de Mytela sp. em posição de vida e fragmentos de conchas são observados nesse intervalo. No intervalo de 260 a $471 \mathrm{~cm}$, ocorrem as unidades estratigráficas lama-areia estuarina e areias marinhas, representativas de uma sequiência transgressiva (Souza Filho 1995; Souza Filho \& El-Robrini, em preparação) (Figura $10 \mathrm{C}$ ).

\section{Sedimentação}

O processo de formação dos cheniers é dominado pela ação de ondas, durante eventos de marés de sizígia, quando ocorre um aumento de energia no ambiente litorâneo, produzindo uma variação episódica no suprimento sedimentar, que devido a intensificação da ação de ondas e correntes de marés retrabalha os sedimentos, removendo os sedimentos pelíticos e depositando as areias. Esse processo marca períodos erosivos da linha de costa, responsáveis pela interrupção da progradação lamosa.

Em outros casos, o registro de "erosão, deposição e migração" dos cheniers pode ocorrer simultaneamente, e as variações de longo período no nível do mar ou no suprimento sedimentar não se fazem necessários para explicar a formação episódica dos cheniers (Anthony 1989).

\section{Planície Arenosa}

\section{Litofácies (Areia Fina a Muito Fina)}

É constituída por areias quartzosas bem selecionadas, de coloração cinza muito claro (N8), apresentando alguns fragmentos de conchas e micas. A parte superior (0 - 200 $\mathrm{cm})$ é marcada por uma estruturação maciça, enquanto o intervalo subseqüente $(200-350 \mathrm{~cm})$ é caracterizado por apresentar estratificações plano-paralelas e cruzada tangencial e marcas onduladas, além de acamamento flaser simples, tubos de bioturbação preenchidos por lama de cor cinza médio (N5) e clastos de argila retrabalhados (Figura 10 D).

\section{Sedimentação}

A planície arenosa é dominada, principalmente, por correntes de marés, onde os sedimentos são continuamente retrabalhados. Os sedimentos finos são submetidos ao processo de ressuspensão, permanecendo as areias quartzosas finas a muito finas. As estruturas sedimentares consistem em sand Waves de até $13 \mathrm{~m}$ de comprimento e $50 \mathrm{~cm}$ de altura, superimpostas por ondulações. Essas estruturas sedimentares, com orientação preferencial NE, mostram a forte influência das correntes de marés, indicando o sentido da maré vazante. Camadas planas são desenvolvidas nas zonas de espraiamento, enquanto estratificações cruzadas são os tipos de acamamento dominantes, orientadas segundo a direção da corrente de maré enchente e vazante. As estruturas biogênicas mais freqüientes são os tubos de bioturbação verticais.

\section{Dunas Costeiras}

\section{Litofácies (Areia muito fina)}

Apresenta uma espessura superior a $4 \mathrm{~m}$. É constituída por areias quartzosas muito finas, de coloração cinza muito claro (N8), angulares, bem selecionadas, apresentando alguns fragmentos de conchas e micas. As dunas longitudinais apresentam estratificação cruzada tabular de grande porte, mergulhando $26^{\circ} / 210^{\circ} \mathrm{Az}$ e marcas de raízes; enquanto as dunas piramidais (Goldsmith 1978) apresentam camadas mergulhando no sentido oposto à linha de crista da duna, que é paralela à direção preferencial do vento $\left(270^{\circ} \mathrm{Az}\right)$. A direção de mergulho das camadas oblíquas é bissetada pela direção do vento preferencial, resultando na estratificação cruzada obliqua. 


\section{Sedimentação}

Os sedimentos são oriundos da planície arenosa e das praias. Durante a maré baixa, os sedimentos arenosos muito finos são retrabalhados pelo vento e transportados para o pós-praia, dando origem assim aos campos de dunas móveis barcanóides e piramidais, e dunas longitudinais fixadas. Atualmente, as dunas migram sobre os depósitos de manguezal.

Esta região possui condições favoráveis para acumulação destes depósitos, devido ao grande suprimento de areias (fonte proximal) e fortes ventos alíseos de NE e E.

\section{Praias}

\section{Litofácies (areia fina a muito fina)}

Apresenta até $3 \mathrm{~m}$ de espessura (Figura $10 \mathrm{E}$ ), desenvolvendo-se sobre os manguezais de intermaré. São comuns as estratificações de baixo ângulo, geradas a partir da migração de marcas onduladas. São constituídas, em profundidade, por areias quartzosas finas, bem selecionadas, angulosas, com estratificação cruzada planar de baixo ângulo, que caracteriza a fácies de praia; não apresenta microfauna. Em geral, os sedimentos arenosos migram sobre o manguezal de intermaré, constituindo deste modo praias transgressivas (Figura 10 E).

\section{Sedimentação}

A praia é dominada por processos de macromaré e durante um ciclo de maré, a posição da zona de espraiamento, surf e arrebentação é modificada com a maré tanto na vertical como na horizontal em direção à linha de preamar e baixamar (Masselink \& Short 1993). Os processos de espraiamento e surf dominam a zona de intermaré superior do estirâncio, onde o sistema de calhas e cristas (ridges and runnels) desenvolve-se, ficando exposto durante os níveis de marés baixas. Nas cristas, as principais estruturas sedimentares são as ondulações com estratificação cruzada, formadas em regime de fluxo superior, durante a maré alta. No entanto, com a subida e descida da maré, ocorrem nas zonas de espraiamento, camadas planas. Nas calhas, correntes canalizadas formam ondulações superimpostas a aquelas formadas por ondas.

\section{DISCUSSÕES E CONCLUSÕES}

A Planície Costeira Bragantina é um sistema bastante dinâmico, onde os processos sedimentares tem estado ativos durante o Holoceno.

\section{-Limite Interno da Planície Costeira Bragantina}

O limite do Planalto Costeiro com a Planície Costeira é marcado por uma linha de falésias mortas, a partir das quais sucedem-se os manguezais de intermaré, responsáveis pela progradação da linha de costa. A distinção morfológica desses ambientes é baseada, principalmente, na altimetria relativa, que induz tempos de inundação diferentes, fazendo com que os manguezais de supramaré possuam uma estrutura arbórea de menor porte, produto, provavelmente, das condições físicoquímicas dos sedimentos (alta salinidade, maior adensamento, menor quantidade de nutrientes e menor aeração). As falésias mortas situam-se à $25 \mathrm{~km}$ da linha de costa atual e são indicadoras do nível de mar mais alto do Holoceno, muito bem conhecido também na costa leste brasileira como Transgressão Holocênica (5.100 anos A.P.), responsável pelo afogamento de cursos fluviais, que evoluiram para estuários e pântanos salinos (Suguio et al. 1985; Domingues et al. 1992; Martin et al. 1993; Souza Filho, 1995; Souza Filho \& El-Robrini, em preparação).

\section{-Pântanos Salinos ou "Campos de Bragança”}

Os pântanos salinos internos são instalados em antigos embaiamentos costeiros, desenhando uma paleorede de drenagem (Figura 2); enquanto os pântanos salinos externos preenchem depressões, provavelmente, associadas aponds ou pequenas lagunas. Segundo Souza Filho \& El-Robrini (em preparação), os sedimentos dos pântanos salinos constituem a primeira fase de sedimentação transgressiva da Planície Costeira Bragantina, representando o limite mais inferior do trato de sistema transgressivo.

\section{- Cheniers}

São feições que marcam períodos erosionais, que interrompem a progradação lamosa da linha de costa (Hoyt, 1969; Augustinus, 1989). Oscheniers observados na área de estudo, apresentam dois processos evolutivos distintos: (1) os cheniers formados por cordões de praia linear, têm seu desenvolvimento associado à formação de flexas arenosas (spits), a partir do transporte de areias por correntes de marés, na foz de canais de marés (Figura $8 \mathrm{E}$ ); segundo Silveira et al. (em preparação), normalmente estes cheniers estão ligados à morfologia de antigas baías, mostrando que eles são formas acrecionárias, resultantes de processos erosivos e; (2) os cheniers que apresentam formas irregulares, com cordões de dunapraia (dune-beach ridge) (Figura $8 \mathrm{D}$ ), estão relacionados ao retrabalhamento por ondas dos sedimentos e posterior ação de processos de deflação, que transpotam as areias, formando os cordões de dunas. Ambos os cheniers migram em direção ao continente durante as marés de sizígia, em decorrência dos processos de leques de lavagem, que produzem mudanças morfológicas significativas.

\section{-Cordão Duna-Praia}

Os cordões de duna-praia são formados a partir do retrabalhamento das areias finas da planície arenosa, que migram sobre os depósitos de manguezais de intermaré.

A planície bordeja toda a planície lamosa (manguezais), constituindo o fundo das baías costeiras, repre-sentando os baixios arenosos, cujos sedimentos, segundo Faria Jr et al. (1987) e El-Robrini et al. (1992b), são oriundos principalmente de antigos estoques de areias costeiras relictas, submersas na Plataforma Interna do Pará/Maranhão, com menor contribuição dos rios que recortam o Planalto Costeiro. 


\section{-Morfologia da Rede de Drenagem Estuarina}

Na planície estuarina, a morfologia do canal estuarino apresenta características peculiares em cada segmento. Dalrymple et al. (1992) apresentam um modelo de fácies estuarinas, onde a geometria na forma de funil é típica de estuários dominados por macromarés, apresentando barras arenosas de marés e planícies arenosas e no segmento reto-meandrante-reto ocorrem barras de meio de canal e em pontal, o que é observado no estuário do Rio Caeté. No segmento reto, as correntes de marés redistribuem rapidamente os sedimentos, o que resulta no preenchimento do estuário, propiciando o desenvolvimento da forma clássica de funil. Esses mesmos autores afirmam que a presença do segmento reto-meandrante-reto indica que o transporte de carga de fundo se dá em direção ao continente, caracterizando um ambiente estuarino e, portanto, uma costa transgressiva.

\section{-Modelo Deposicional}

A estratigrafia recente da planície costeira (Figura 11), mostra uma sequência transgressiva basal (S1), constituída por areias e lamas de origem marinha/estuarina na base $(3-6 m)$, seguida por uma sequência regressiva de lamas orgânicas de planícies de maré (manguezal) (S2), situados atrás de um cordão arenoso transgressivo atual (S3)(Souza Filho 1995).

A sequência sedimentar vertical geral da planície de maré é caracterizada por uma granodecrescência ascendente, composta por areias da planície arenosa na base, sobreposta por lamas da planície lamosa (manguezal) de intermaré e supramaré (Souza Filho 1995). A espessura total dessa sequência varia de $3 \mathrm{~m}$ a mais de $6 \mathrm{~m}$ e está depositada sobre a sequência fluvial e areias marinhas da sequência transgressiva inferior (S1).

O ambiente de pântano salino externo é também influenciado pelas marés e está depositado sobre depósitos da planície de maré lamosa e arenosa, representando uma sequência de preenchimento de depressões, provavelmente associadas a lagoas (ponds) ou pequenas lagunas.

Atualmente a sequência regressiva (S2) está sendo sobreposta por uma sequência marinha transgressiva (S3), representada por dois ambientes de sedimentação distintos: estuarino e litorâneo.

A geometria dos canais estuarinos mostra o estágio evolutivo avançado de preenchimento, apresentando (m)

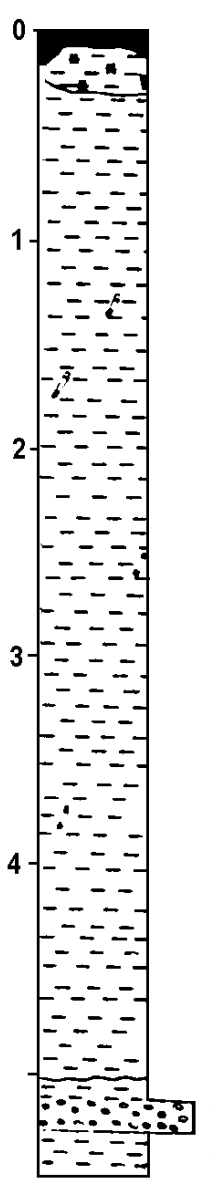

A (m)

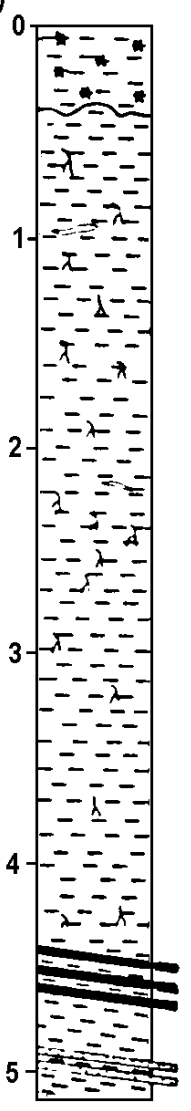

B (m)

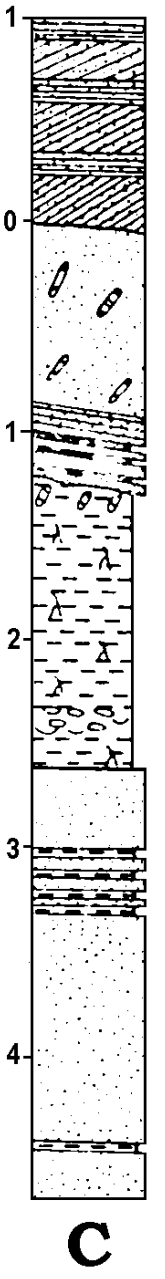

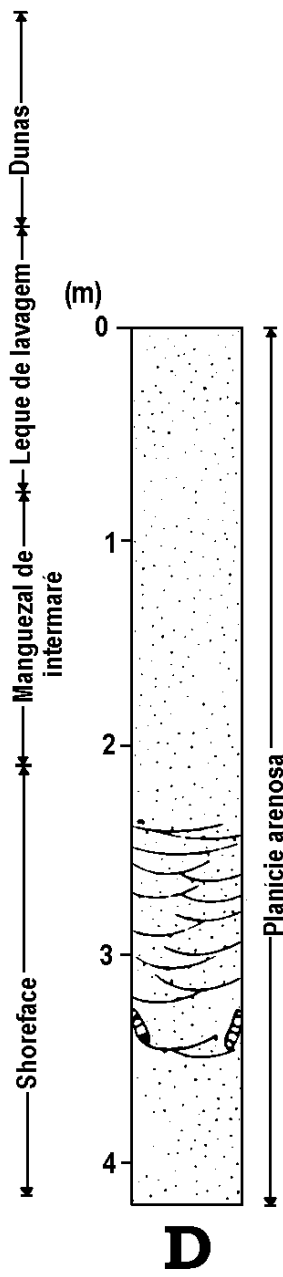

(m)

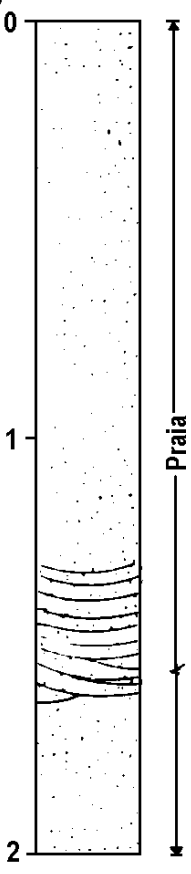

E

Figura 10: Seqüencias estratigráficas dos principais ambientes morfo-sedimentares da Planície Costeira Bragantina. A- Pântano Salino; B-Manguezal; C-Chenier; D-Planície Arenosa; E-Praia.

Figure 10: Stratigraphic sequences of the majors morpho-sedimentary environments of Bragança Coastal Plain. A-Salt marsh; B-Mangrove; C-Chenier; D-Sand flat; E-Beach. 
portanto deltas de maré vazante na foz de alguns estuários.

Os ambientes litorâneos são influenciados pelas correntes de marés, de deriva litorânea, ondas e, em menor intensidade, por correntes fluviais. Os depósitos eólicos e de praia observados migram, a partir da linha de costa, em direção ao continente sobrepondo-se aos depósitos de manguezais da planície de maré. A sequência estratigráfica vertical deste ambiente litorâneo é composta por sedimentos de praia, sobrepostos por sedimentos das dunas eólicas, ambos depositados sobre os sedimentos lamosos de manguezal de intermaré.

O modelo sedimentar proposto para a Planície Costeira Bragantina mostra uma sistema deposicional costeiro complexo, constituído por diferentes ambientes de sedimentação (fluvial, estuarino, planície de maré, parálico e litorâneo) e características sedimentares, estratigráficas e morfológicas peculiares, no que diz respeito à geometria e distribuição espacial dos ambientes (Souza Filho 1995) (Figura 11). Este modelo deposicional é composto de um sistema de planície costeira de macromaré flúvial-estuarina-planície de maré, com cordão duna-praia barreira (dune-beach ridge) associado.

\section{AGRADECIMENTOS}

Os autores agradecem ao Conselho Nacional de Desenvolvimento Científico e Tecnológico (CNPq) pela concessão da bolsa de mestrado ao primeiro autor desse trabalho; ao Curso de Pós-Graduação em Geologia e Geoquímica do Centro de Geociências da Universidade Federal do Pará (CPGG/CG/UFPA) pelo financiamento das etapas de campo e utilização dos laboratórios. Ao MSc. Márcio Sousa da Silva pela inestimável ajuda nos trabalhos de campo e discussões. Ao Prof. Dr. Mário Vicente Caputo (CPGG/CG/UFPA), ao pesquisador MSc. Amilcar Carvalho Mendes (CNPq/Museu Paraense Emílio Goeldi) e à doutoranda Odete Fátima Machado da Silveira (CPGG/CG/UFPA) pelas sugestões e leitura crítica do trabalho.

\section{REFERÊNCIAS BIBLIOGRÁFICAS}

ABREU, F.A.M. \& LESQUER, A. 1985. Considerações sobre o Pré-Cambriano da região sul-sudeste do Craton São Francisco. In: SIMPÓSIO DE GEOLOGIA DA AMAZÔNIA, 2., Belém. Anais... Belém, SBG - Núcleo Norte, 1985. 7-21.

ALLEN, G.P. \& POSAMENTIER, H.W. 1994. Transgression facies architecture in mixed-and-wave dominated incised-valley: example from the Gironde Estuary, France. In: DALRYMPLE, R.W.; BOYD, R; ZAITLIM, B.A. (edits). Incised-Valley Systems: Origem and Sedimentary Sequences. SEPM, sp. publ. n'51, Tulsa, p: 225-240.

ANTHONY, E.J. 1989. Chenier plain development in Northern Sierre Leone, West Africa. Marine Geology, 90 (4): 297-309.

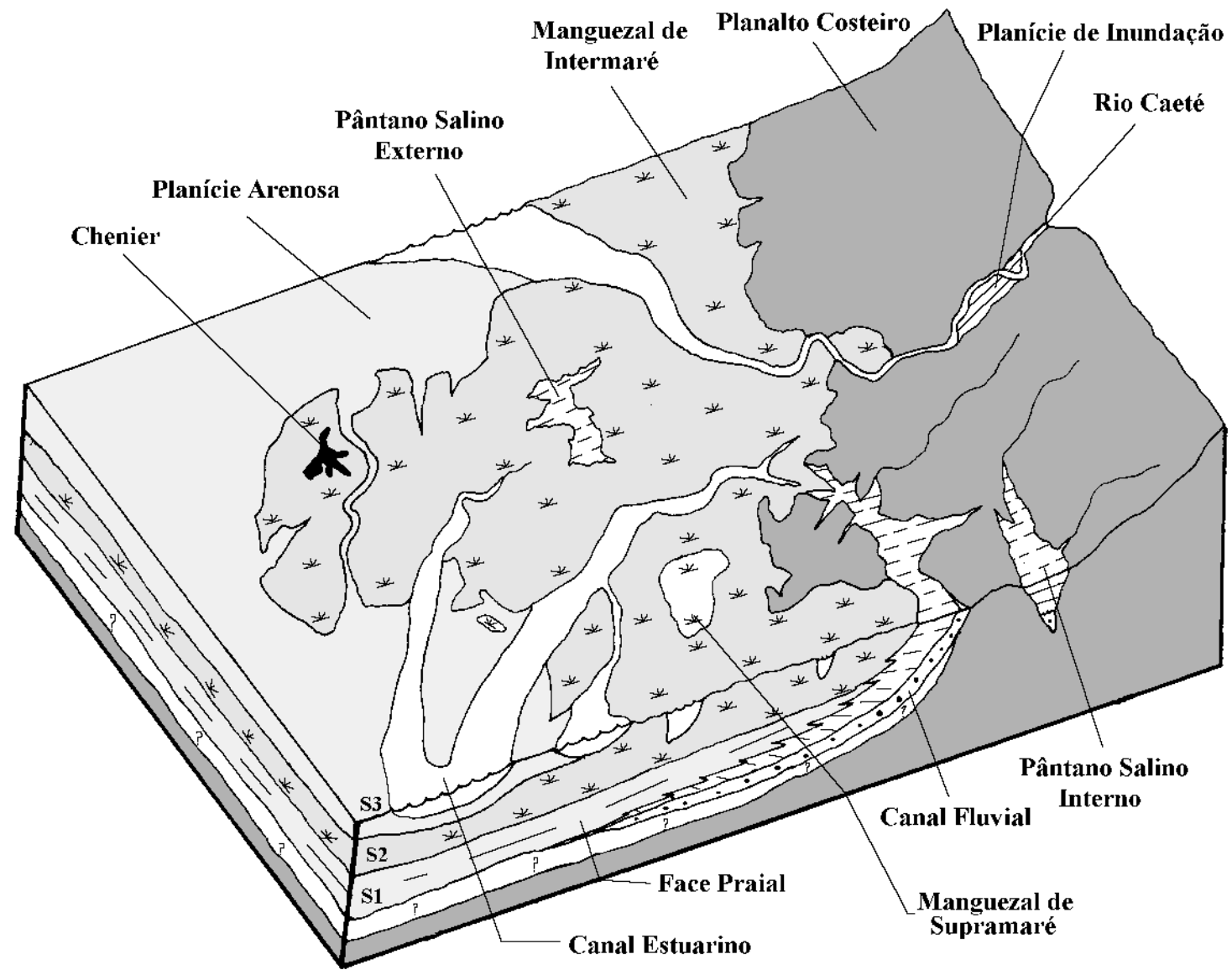

Figura 11: Bloco diagrama mostrando um corte longitudinal ao ambiente pântano salino e a distribuição espacial e geométrica dos ambientes sedimentares da Planície Costeira Bragantina em situação de baixa-mar. Figure 11: Diagram block showing a longitudinal section in the salt marsh environment and the spacial and geometric distribution of the sedimentary environments of Bragança Coastal Plain in ebb tide situation. 
ARAI, M.; TRUCKENBRODT, W.; NOGUEIRA, A.C.R.; GÓES, A.M. \& ROSSETTI, D.F. 1994. Novos dados sobre a estratigrafia e ambiente deposicional dos sedimentos Barreiras, NE do Pará. In: SIMPÓSIO DE GEOLOGIA DA AMAZÔNIA, 4., Belém. Anais... Belém, SBG - Núcleo Norte, 1994. 185-187.

ARAI, M.; UESUGUI, N.; ROSSETTI, D.F. \& GÓES, A.M. 1988. Considerações sobre a idade do Grupo Barreiras no nordeste do Estado do Pará. In: CONGRESSO BRASILEIRO DE GEOLOGIA, 35., Belém. Anais... Belém, SBG, 2: 738-752.

ARANHA, L.G.F.; LIMA, H.P.; SOUZA, J.M.P. \& MARINHO, R.K. 1990. Origem e evolução das bacias de Bragança-Viseu, São Luís e Ilha Nova. In: RAJA GABAGLIA, G.P. \& MILANI, E.J.(edits) Origem e Evolução de Bacias Sedimentares. Rio de Janeiro, PETROBRÁS. 221-233.

AUGUSTINUS, P.G.E.F. 1989. Cheniers and cheniers plains: a general introduction. Marine Geology, 90(4): 219-229.

COSTA, J.B.S.; BORGES, M.S.; BEMERGUY, R.L.; FERNANDES, J.M.G.; COSTA Jr., P.S. \& COSTA, M.L. 1993. Evolução cenozóica da Região de Salinópolis, Nordeste do Estado do Pará. Geociências, 12(2): 353-372.

DALRYMPLE, R.W.; KNIGHT, R.J.; ZAITLIN, B.A.; MIDDLETON, G.V. 1990. Dynamics and facies model of a macrotidal sand-bar complex, Cobequil Bay-Salmon River estuary (Bay of Fundy). Sedimentology, 37: 577-612.

DALRYMPLE, R.W.; ZAITLIN, B.A.; BOYD, R. 1992. Estuary facies models: conceptual basis and stratigraphic implications. Journal of Sedimentary Petrology, 62(2): 1130-1146.

DEPARTAMENTO DE HIDROGRAFIA E NAVEGAÇÃO (DHN). 1995. Tábuas de Marés PARA 1994. Costa do Brasil e alguns portos estrangeiros. Rio de Janeiro, DHN. p. 1-6.

DOMINGUES, J.M.L.; BITTENCOURT, A.C.S.P. \& MARTIN, L. 1992. Controls on Quaternary coastal evolution of the eastnortheastern coast of Brazil: roles of sea level history, trade winds and climate. Sedimentary Geology, 80: 213-232.

EL-ROBRINI, M. 1992. Évolution rapide des fonds d'une zone estuarine: le secteur D'Itaqui-Baie São Marcos - Maranhão (Brésil). In: PROST, M.T. (edits) Évolution des littoraux de Guyane et de la Zone Caraïbe Méridionale pendant le Quaternaire. Paris, ORSTOM. p. 159-176.

EL-ROBRINI, E.; SOUZA FILHO, P.W.M.; SILVA, C.A.; SILVEIRA, O.F.M.; FARIA Jr, L.E.C. \& MENDES, A.C. 1992a- Registro das oscilações do nível do mar na plataforma continental norte do Brasil. In: SIMPÓSIO INTERNACIONAL DO QUATERNÁRIO DA AMAZôNIA, 1992, Manaus. Resumos. Manaus, INQUA, 1992. 73-75.

EL-ROBRINI, E.; FARIA Jr., L.E.C.; TORRES, A.M.; SILVA, M.S.; SOUZA FILHO, P.W.M. \& SILVA, M.S. -1992bDeposição e assoreamento das rias do nordeste do estado do Pará . In: CONGRESSO BRASILEIRO DE GEOLOGIA, 37, 1992, São Paulo. Anais... São Paulo, SBG, 1992. 1: 79.

EL-ROBRINI, M. \& SOUZA FILHO, P.W.M. Amazon Continental Shelf and Evidences of Sea Level Changes During the Late Quaternary. No prelo.

FARIA Jr., L.E.C.; MARÇAL, M. S. \& PINHEIRO. R.V.L. 1987. A dinâmica sedimentar da praia do Maçarico/Salinópolis e sua importância para a geologia da região costeira do Estado do Pará. In: CONGRESSO DA ASSOCIACC̃̃O BRASILEIRA DE ESTUDOS DO QUATERMÁRIO, 1, 1987, Porto Alegre. Anais... Porto Alegre, ABEQUA. 1987. 343-356.

FIGUEIREDO JR., A.G. 1990. Normas de controle de qualidade para processamento de testemunhos inconsolidados. Projeto Sedimentos de talude, Contrato PETROBRÁS/ UFF n ${ }^{\circ} 3-570$ 794-0-90, 27p.

FRANZINELLI, E. 1982. Contribuição a geologia da costa do Estado do Pará (entre as baías de Curuçá e Maiaú). In: SIMPÓSIO INTERNACIONAL DE QUATERNÁRIO, 4, 1982, Manaus. Atas...Manaus, INQUA. 305-322.

FRANZINELLI, E. 1992. Evolution of the geomorphology of the coast of the State of Pará, Brazil. In: PROST, M.T.(edits) Évolution des littoraux de Guyane et de la Zone Caraïbe Méridionale pendant le Quaternaire. Paris, ORSTOM. 203230

FREY, R.W. \& BASAN, P.B. 1978. Coastal salt marsh. In: DAVES
Jr., R.A. (edits) Coastal Sedimentary Environments. New York, Springer-Verlag. $420 \mathrm{p}$

GÓES, A.M.; ROSSETTI, D.F.; NOGUEIRA, A.C.R.; TOLEDO, P.M. 1990. Modelo deposicional preliminar da Formação Pirabas no nordeste do Estado do Pará. Boletim do Museu Paraense Emílio Goeldi, 2: 3-15.

GOLDSMITH, V. 1978. Coastal Dunes. In: DAVES Jr., R.A. Coastal Sedimentary Environments. New York, SpringerVerlag. 420 p.

HOYT, J.H. 1969. Chenier versus Barrier, genetic and stratigraphic distinction. The Americam Association of Petroleum Geologist Bulletin, 53(2): 299-306.

IGREJA, H.L.S. 1991. Aspectos tectono-sedimentares do Fanerozóico do nordeste do Pará e noroeste do Maranhão, Brasil. Belém, UFPA. 1991, Tese de Doutoramento. 191 p.

LARSONNER, C. 1975. Tidal Deposits, Mount Saint-Michel Bay, France. In: GINSBURG, R.N. (edits) Tidal Deposits. SpringerVerlag, New Yprk. 21-30.

KAMALUDIN, B.H. 1993. Tha changing mangrove shorelines in Kuala Kurau, Peninsular Malaysia. Sedimentary Geology, 83: 187-197.

MARTIN, L. SUGUIO, K.; FLEXOR, J.M. 1993. As flutuações do nível do mar durante o Quaternário Superior e a evolução gelógica dos "deltas" brasileiros. Boletim do IG-USP, sp. publ, 15: $86 \mathrm{p}$.

MARTORANO, L.G.; PERREIRA, L.C.; CÉZAR, E.G.M.; PEREIRA, I.C.B. 1993. Estudos Climáticos do Estado do Pará, Classificação Climática (KÓPPEN) e Deficiência Hídrica (THORNTHWHITE, MATHER). Belém, SUDAM/ EMBRAPA, SNLCS. 53p.

MASSELINK,G. \& SHORT, A.D.1993. The effect of tide range on beach morphodynamics and morphology: a conceptual beach model. Journal of Coastal Research, 9(3): 785-800.

MENDES, A.C. 1994. Estudo sedimentológico e estratigráfico dos sedimentos holocênicos da Costa do Amapá - Setor entre a Ilha de Maracá e o Cabo Orange. Belém, UFPA. 1994, Dissertação de Mestrado. 276p.

PRYOR, W.A. 1975. Biogenic sedimentation and alteration of argillaceous sediments in shallow marine environments. Geological Society of American Bulletin, 86: 1244-1254.

ROSSETTI, D.F.; TRUCKENBRODT, W.; GÓES, A.M. 1989. Estudo paleoambiental e estratigráfico dos sedimentos barreiras e Pós-Barreiras na Região Bragantina, Nordeste do Pará. Boletim do Museu Paraense Emílio Goeldi, 1: 25-74.

SÁ, J.H.S. 1969. Contribuição a geologia e os sedimentos terciários e quaternários da Região Bragantina. Boletim do Instituto de Geologia do Rio de Janeiro, 3: 21-36.

SEMENIUK, V. 1981. Sedimentology and stratigraphic sequence of a tropical tidal flat, North-Western Australia. Sedimentary Geology, 29: 195-221.

SEMENIUK, V. 1993. The Pilbara Coast: a riverine coastal plain in a tropical arid setting, northwestern Australia. Sedimentary Geology, 83: 235-256.

SILVEIRA, O.F.M.; NITTROUER, C.A.; MENDES, A.C.; ALLINSON, M.; PROST, M.T.; FIGUEIREDO, A.G. \& FARIA Jr. L.E.C. Chenier Plains at the Amapá Coastal Plain (North Amazon River Mouth). Em preparação.

SOUZA FILHO, P.W.M. 1995. Influência das Variações do Nível do Mar na Morfoestratigrafia da Planície Costeira Bragantina (NE do Pará) durante o Holoceno. Belém, UFPA. 1995, Dissertação de Mestrado. 123 p.

SOUZA FILHO, P.W.M. \& EL-ROBRINI, M. 1995. Um exemplo de sistema deposicional dominado por macromaré: A Planície Costeira Bragantina - NE do Pará (Brasil). In: CONGRESSO DA ASSOCIAÇÃO BRASILEIRA DE ESTUDOS DO QUATERNÁRIO, 5, 1995, Niterói, Anais... Niterói, ABEQUA, 1995. 278-284.

SOUZA FILHO, P.W.M. \& EL-ROBRINI, M. Stratigraphic sequences, morphostratigraphy and facies models associated with sea level changes during holocene: an example in the Bragança Coastal Plain (Northeast of Pará), Brazil. Em preparação.

SUGUIO, K. 1973. Introdução a Sedimentologia. São Paulo, Edgard Blücher. 342p. 
SUGUIO, K.; BITTENCOURT, A.C.S.P.; DOMINGUEZ, J.M.L.; FLEXOR, J.M.; AZEVEDO, A.E.G. 1985 Flutuações do Nível Relativo do Mar dutante o Quaternário Superior ao longo do Litoral Brasileiro e suas implicações na Sedimentação Costeira. Revista Brasileira de Geociências, 15(4):273-286.

WOODROFFE, C.D. \& MULRENNAN, M.E. 1993. Geomorphology of the Lower Mary River Plains. Northern Territory. Darwin, Australia National University. 152p.
WOODROFFE, C.D.; CHAPPELL, J.; THOM, B.G.; WALLENSKY, E. 1986. Geomorphological Dinamics and Evolution of the South Alligator River and Plains, Northern Territory. Australia National University. North Australia Reseach Unit. Mangrove Monograph no 3. 190p.

WOODROFFE, C.D.; CHAPPELL, J.; THOM, B.G.; WALLENSKY, E. 1989. Depositional models of a macrotidal estuary and flood plain, South Alligator River, Northern Australia. Sedimentology, 36(5): 737-756. 